\title{
重み付き評価指標を用いた 稀少種シオマネキ生息地適性評価手法

\author{
HABITAT EVALUATION MODEL FOR GENUS Uca \\ BY USING OF WEIGHTED EVALUATION ITEMS
}

\author{
宇野 宏司 ${ }^{1} \cdot$ 中野 晋 $^{2} \cdot$ 古川 忠司 ${ }^{3}$ \\ Kouji UNO, Susumu NAKANO and Tadashi FURUKAWA
1学生会員 修 (工) 徳島大学大学院 工学研究科博士後期課程（T770-8506 徳島市南常三島町 2-1）
${ }^{2}$ 正会員 博 (工) 徳島大学助教授 工学部建設工学科（テ770-8506 徳島市南常三島町 2-1）
3 学生会員＼cjkstart徳島大学 工学部建設工学科（兵770-8506 徳島市南常三島町 2-1）

\begin{abstract}
In this paper, results of analysis on habitat suitability of genus Uca which is selected as a near - threatened specie in Japan were presented. Study sites were tidal flats around SHIKOKU Island in Japan. In this study, first, based on the results both of field observations and numerical simulations, data of mud property, characteristics of larvae stage, vegetation and topography feature were collected. Secondary, using multivariate analysis, evaluated items were chosen and were given weighing factor respectively. Thirdly, SI (Suitability Index) curves for each evaluated item were plotted with considering the results of field observations and numerical simulations. Finally, HSI (Habitat Suitability Index) was calculated by multiplying each SI curves score and the HSI value among the tidal flats was compared. Main results are as follows: 1) Considering not only species themselves but also surrounding topography is important. 2) Multivariate analysis is effective to select evaluated items. 3) The limited HSI score of Uca arcuata is 0.6 and that of Uca lactea is 0.4 .
\end{abstract}

Key words: Uca arcuata, Uca lactea, HSI analysis, multivariate analysis

\section{1. はじめに}

近年，小中学生に対する環境教育の普及や地元ボラ ンティアの地道な活動によって, 干潟生態系の重要性が 幅広い世代にわたって認識されるようになり, 全国各地 の干潟ではその保全にむけて様々な努力がなされている. 戦後急速に失われたとされるこの空間に対し，少なくと も現存する干潟がそのまま保全されることがのぞましい が, 利便性, 防災上の観点から，人為的に手を加えざる をえないケースも依然として残されている，また，地球 温暖化による海面上昇の影響をうけて, 沿岸域の干潟が 急速に失われる可能性毛指摘されている。このため，干 潟の諸機能を定量的に評価し，何らかのインパクトが与 えられた場合でも，以前と同等あるいはそれ以上の機能 を補償・創造する技術の開発が急務となっている.

我が国で提案された干潟の生物生息環境の定量的評 価としては，米国で開発された生息地適性評価手法 (HEP : Habitat Evaluation procedure) のなか (Habitat Suitability Index : 生物生息環境適合度指数) を

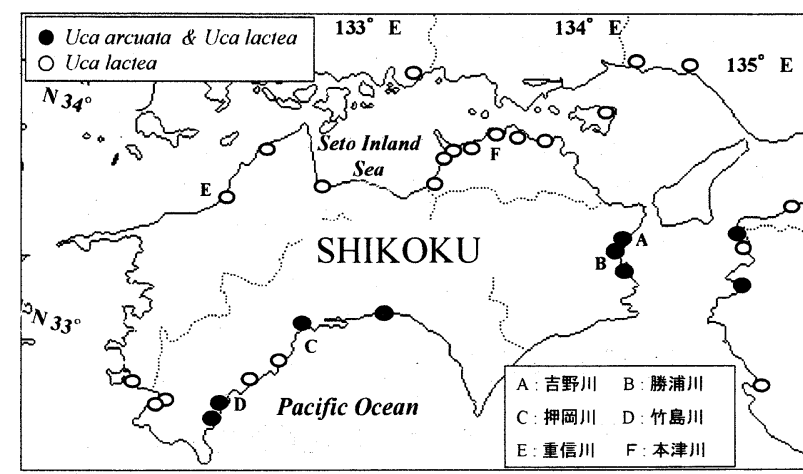

図-1 四国周辺の Uca 属生息分布状況

(2002 年 9 月現在)

アサリや多毛類に適用した報告がある 12,2,3). 著者らも環 境省のレッドリストで「準絶滅危惧種」に指定されてい ろシオマネキ（十脚甲殼類スナガニ科シオマネキ 属:genus $I j c u$ ） を対象にした生息地適性評価ならびに本 種の生息適性からふが染潟の存在価値について考察をお 
表 - 1 主な $U c a$ 属生息地と河川・潮汐・地形情報

\begin{tabular}{|c|c|c|c|c|c|c|}
\hline \multirow{3}{*}{ 河川名 } & \multicolumn{2}{|c|}{$\begin{array}{c}\text { 德鼻県 } \\
\end{array}$} & \multicolumn{2}{|c|}{ 高知県 } & \multirow{2}{*}{$\begin{array}{l}\text { 愛媛県 } \\
\text { 重信川 }\end{array}$} & \multirow{2}{*}{$\begin{array}{l}\text { 香川県 } \\
\text { 本津川 }\end{array}$} \\
\hline & 吉野川 & 勝浦川 & 押岡川 & 竹島川 & & \\
\hline & $A$ & $\mathrm{~B}$ & $\mathrm{C}$ & $\mathrm{D}$ & $E$ & $F$ \\
\hline 緯 度 & $34 / 04 / 43.4$ & $34 / 02 / 13.3$ & $33 / 24 / 22.7$ & $32 / 56 / 14.9$ & $33 / 48 / 13.9$ & $34 / 20 / 49.5$ \\
\hline 経 度 & $134 / 34 / 36.1$ & $134 / 34 / 37.0$ & $133 / 17 / 51.8$ & $132 / 58 / 38.3$ & $132 / 41 / 44.8$ & $134 / 00 / 36.7$ \\
\hline 活動数 (Uca arcuata) & $6.8 / \mathrm{m}^{2}$ & 5 & 1.9 & 3.5 & 0 & 0 \\
\hline 活動数 (Uca lactea) & $12.3 / \mathrm{m}^{2}$ & 15.3 & 1 & 1 & 13.5 & 30 \\
\hline $\begin{array}{c}\text { Uca属生息干潟 } \\
\text { 面積概数 }\left(\mathrm{m}^{2}\right) \\
\end{array}$ & 30000 & 1200 & 40 & 800 & 40000 & 30000 \\
\hline 河口からの距離(km) & $2.0-2.8$ & $1.8-2.3$ & 1.4 & 2.5 & 0.8 & $0.4-0.8$ \\
\hline 河口低水路幅 $(m)$ & 480 & 120 & 300 & - & 200 & 120 \\
\hline 潮汐振幅 (大潮時) & $62.32 \mathrm{~cm}$ & 62.32 & 71.13 & 74.59 & 141.95 & 88.59 \\
\hline 電気伝導度 $(\mathrm{mS} / \mathrm{cm})$ & 32.5 & 29.3 & 23.6 & 21.3 & 65.8 & 46.2 \\
\hline 含水率 $(\%)$ & $10.4-40.5$ & $13.1-38.9$ & $17.5-38.8$ & $22.7-33.4$ & $13.9-38.1$ & $14.6-30.0$ \\
\hline 含泥率 $(\%)$ & $2.5-90.4$ & $3.3-67.3$ & $7.7-46.8$ & $39.0-56.5$ & $5.6-46.1$ & $1.5-16.7$ \\
\hline 河口の形態 & 砂州あり & 砂嘴あり & 湾奥 & 閉塞気味 & 閉塞気味 & $-\cdots$ \\
\hline 周辺植生 & ヨシ & $\begin{array}{c}\text { ヨシ } \\
\text { ハマサジ } \\
\text { ハママツナ }\end{array}$ & ヨシ & ヨシ & $\begin{array}{c}\text { ヨシ } \\
\text { ハマサジ }\end{array}$ & $\begin{array}{l}\text { ハマサジ } \\
\text { フクド }\end{array}$ \\
\hline
\end{tabular}

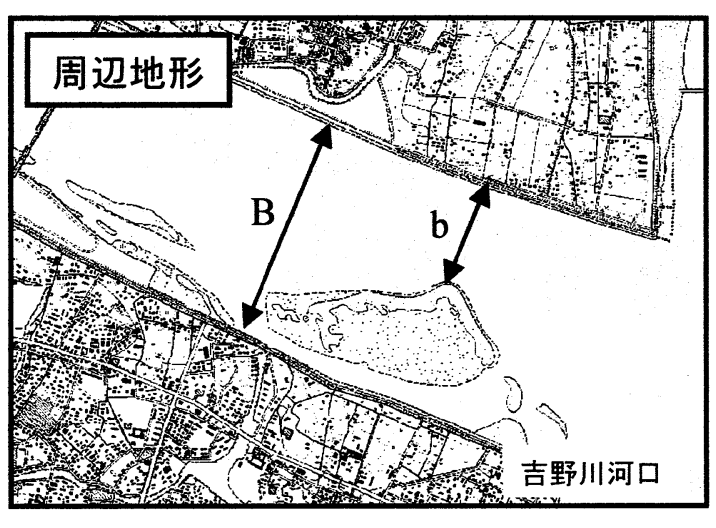

粒度分布
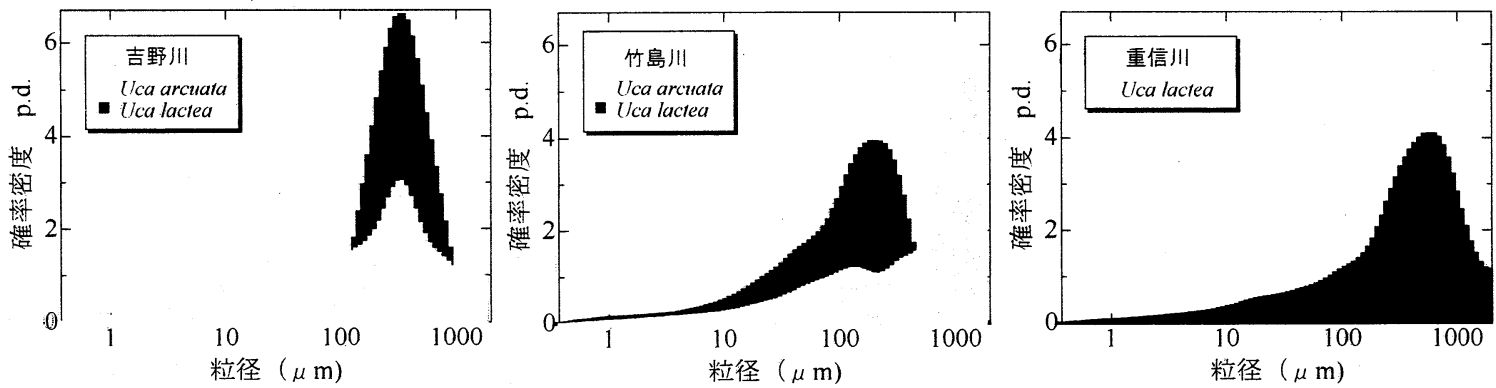

図一2 $U c a$ 属生息地の地形・底質の特徵

こなってきた 4.5 .

しかし, 従来の HSI モデルでは, 評価指標の選択が モデル開発者の染意によるところが大きく，その選択方 法や指標間の重みについては十分に議論されていなかっ た. したがって評価指標の選択によっては適切でない結 果を出寸可能性もある. そこで, 本研究では, 四国周辺 の河口干潟に生息するシオマネキを対象に (1)現地調查 により得られた生息分布・底質・稙生・地形的特徴に関 する知見, (2)HSI モデル構築のための評価指標とシオマ ネキ生活史との関係，(3)多変量解析を用いた HSI モデ 儿評価指標の選択, 重み付方法と適用例, について報 告する.

\section{Uca 属生息地の底質 - 植生 - 地形の特徵}

著者らは，シオマネキ属の生息環境特性を把握するこ とを目的に, 過去 5 年にわたり継続的な現地調查をおこ なっている. 以下, 調查方法の概要と, これまでに得ら れた知見を記す。

\section{（1）調查方法}

吉野川, 勝浦川においては $U c a$ 属活動期（3 月 - 1n 月）の大潮の干潮時に $1 \mathrm{~m}$ 四方の定点コドラート. (17 点)，その他の河川においては活動がピークを迎える7 月末から 8 月中旬にかけて年 1〜こ回，Uca 属の生息が
確認された地点にコドラートを設け，活動個体数調査を おこなった. 調査項目は， $1 \mathrm{~m}$ 四方のコドラート内の種 別, サイズ別, 雌雄別の活動個体数 - 巣穴数・気温 -土 温・電気伝導度・生息位置 $($ 緯度・経度) ・汀線からの 高度である. また，コドラート内の表層の底質を採集し， 含泥率, 含水率, 粒径 $2000 \mu \mathrm{m}$ 以下の粒度分布を求めた. 粒度分析はレーザー粒度分析によった. 得られた分布型 をもとに，底質の粗粒分及び細粒分加”対数正规分分布に徉 うものとして千潟底質の相対頻度を算出し，細粒分およ び粗粒分の中央粒径を求めた.

\section{（2）シオマネキ生息地の底質・植生・地形}

図 - 1に 2002 年 9 月までに著者らによって確認され た四国周辺のシオマネキ (Uca arcuata) ならでにハクセ ンシオマネキ (Uca lactea) の生息分布状況を示す. ま た，表 - 1 に主な $U c a$ 属生息地と河川! 潮汐 ・地形・植 生情報を示す。本種は四国周辺ひ河口干潟で生息が確認 されてい方，な方でも声野引河口にひろがる泥質干潟 ならびに砂州は，有明海沿崖，营崎県本城川河曰につい

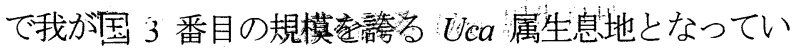
る. 種別にみるとシ神壮生息分布が紀伊水道から 太平洋側に限られているのに対し，ハクセンシオマネキ は四国周辺, 特に瀬戸内海地方の多くの河口干潟で多数 の生息が確認されている.

底質の粒度分布についても両種の間で違いがみらえる。。 


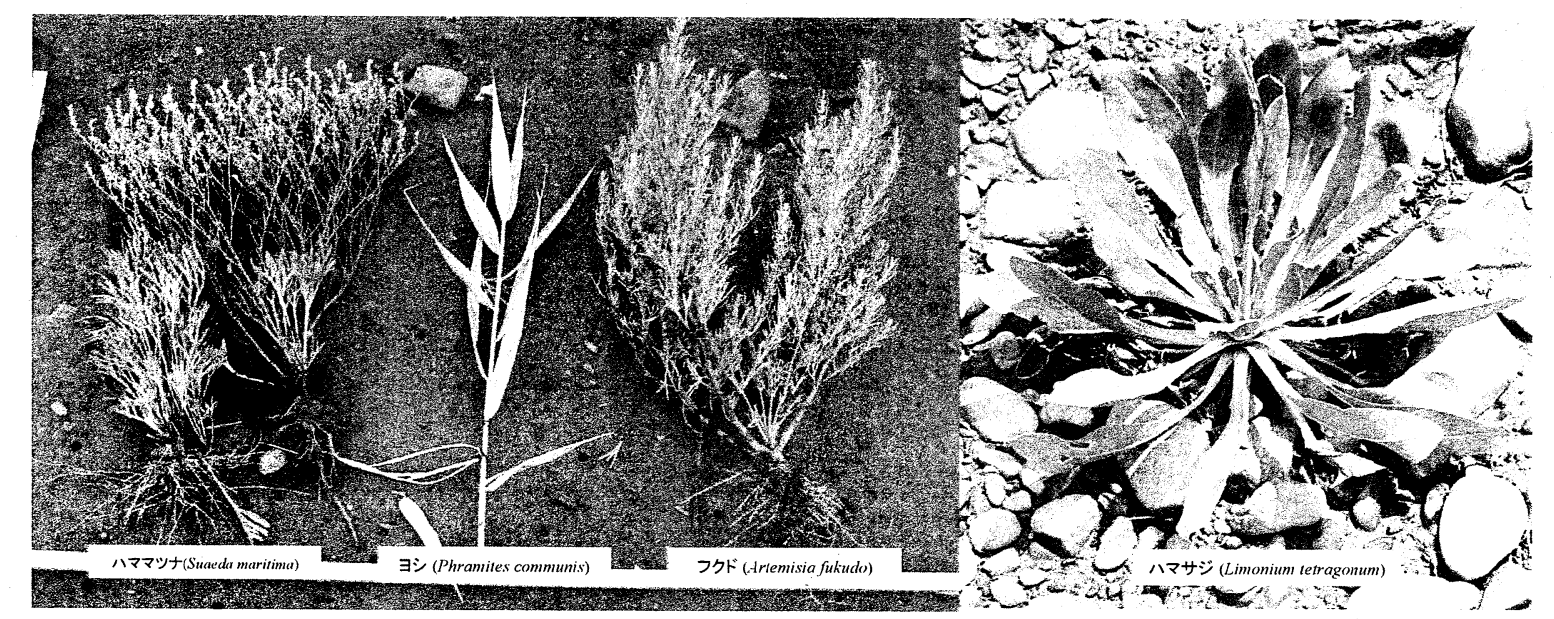

写真-1 Uca 属生息地の植生

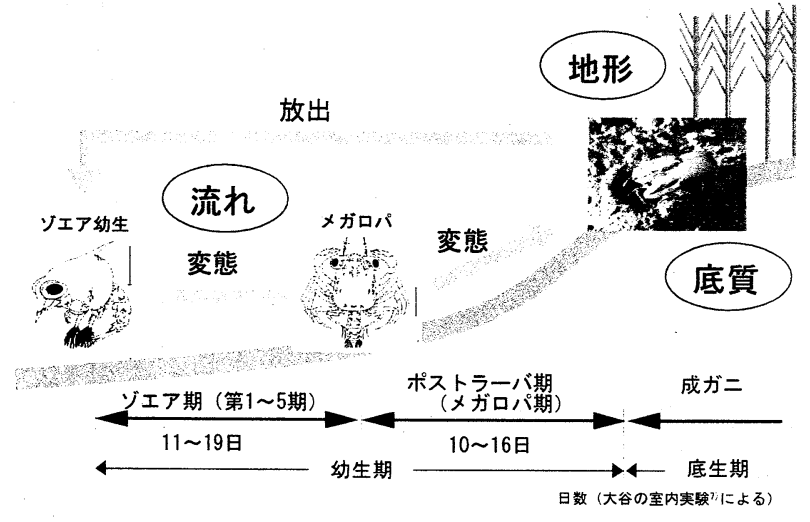

図一3 Uca 属の生活史

一般にシオマネキは, 粒径分布のピークが数 $10 \mu \mathrm{m}$ 付近 と数 $100 \mu \mathrm{m}$ 付近の両方にある泥質に生息しているよう である.これに対しハクセンシオマネキは, 粒径が数 $100 \mu \mathrm{m}$ 前後の限られた範囲に集中する砂質に生息して いる ( 図一2).

$U c a$ 属生息地にみられる植生は，主にヨシ，ハママツ ナ, ハマサジ, フクドなどの塩生植物である(写真-1). このうち, シオマネキの生息地点の周辺には必ずヨシ原 が存在している. この理由として, 鳥などの外敵からの 逃避とヨシ自身による微細粒子のトラップがシオマネキ の摂飭活動に好都合であることが考えられる，一方，八 クセンシオマネキの生息地点には, ヨシの他に, 八マサ ジ，ハママツナ，フクドなどがみられる．しかし，八ク センシオマネキの場合, こうした植生が全く見られない 河口砂州や中洲上でもまとまった個体群が確認されるこ とがある.

$U c a$ 属生息地にはいくつかの共通点が見られることか ら, 空中写真や地形図を用いて Uca 属生息地を事前に 予測したり, ミティゲーションの際に生息可能な候補地 を選定することが可能である ${ }^{6}$. シオマネキの生息地と しては1河口から $3 \mathrm{~km}$ 以内の汽水域内の干潟である, (2)上流からの土砂供給と水量が期待できる河川がある, (3) ヨシ原が存在する, (4)河口閉塞度 ( 図一2 周辺地形 図上での $(1-\mathrm{b} / \mathrm{B}))$ が， 0.4-0.7 程度であること，(5)生
息地への波の直接の侵入が遮断される地形（砂州や砂 嘴）が形成されていることが必要条件である．一方の八 クセンシオマネキは, 条件(1)，(2)を満たせば生息の可能 性があるが，八マサジ等の植生があれば，より質の高い 生息地となることが期待できる.

以上のことから，Uca属の保全を考えるにあたっては， 底質などの物理条件を考慮するだけでなく, 水域も含め た生息地周辺の地形そのものの保全が重要であるといえ る. 特に絶滅が危惧されている稀少種においては, 種の 希少性もさることながら，生息地の地理的条件そのもの が稀少性を帯びているため, こうした稀少空間全体を残 していく努力が必要である.

\section{Uca属生息地適性評価モデルの評価指標}

現地調査の結果から，Uca 属の生息に大きな影響を及 ぼしている因子として, 底質, 陸域 - 水域の連続性, 周 辺地形などが重要であることが指摘された. 本種のよう な干潟生態系を構成する生物の多くは, 複数の生活ステ ージを有するため（図一3）, 生活史を全うできる空閒の 保全が重要である. そこで, 本研究では, 幼生期, 底生 期, 周辺地形のそれぞれで次のような評価指標をとりあ げた.この評㑋指標の選扒作業が，モデルの精度や信賴 性に大きく関わってくるので, 評価指標と対象種の生態 的な意味づけを十分に検討する必要がある.

（1）底質に関する評価指標

底質指標は，底生期の重要な環境因子で，人為的に も管理可能なものである.

a) 含水率 $\cdot$ 含泥率

含水率・含泥率は，いずれも土粒子の粒度構成を 表す指標で, 摂餌や造巣活動のパラメータとなる. 小野 ${ }^{8}$ や山口 9はカニの棲み分け状況を含泥率との関 係より検討している. 吉野川河口では, シオマネキ の場合で含水率が $20-48 \%$ ，含泥率が $10-90 \%$ ，八ク センシオマネキの場合で含泥率が $80 \%$ 以下, 含水率 が 25-35\%の底質に生息している. 
表 - $2 U c a$ 属生息值適性評価のための評価指標

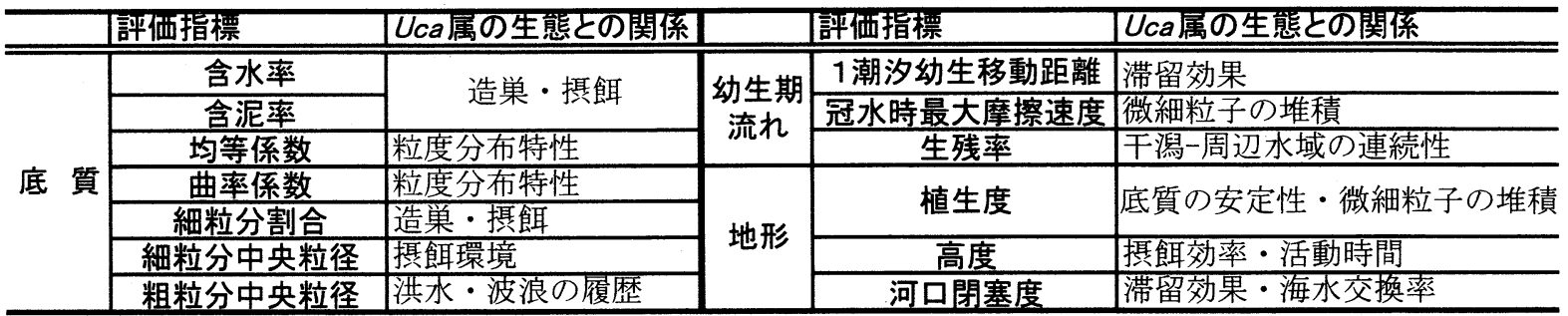

\section{b) 細粒分中央粒径，粗粒分中央粒径}

干潟底質の粒度分布は，洪水末期や平常時に堆積す る細粒分と, 洪水最盛期の高せん断応力状態て堆積す る粗粒分が重合して堆積するため, 複数のピークを持 つことが多く，代表値の選択が難しい，著者らの提案 する干潟の粒度分布式では, 粒度の代表値を細粒分と 粗粒分のそれぞれで算出できる点が，代表值を平均粒 径のみとる場合に比べて優れている. 吉野川河口では, シオマネキ生息地でそれぞれの平均值は $20 \mu \mathrm{m}, 600 \mu \mathrm{m}$ 程度，八クセン生息地で $90 \mu \mathrm{m}, 230 \mu \mathrm{m}$ 程度である.

\section{（2）幼生分散および流れに関する評価指標}

幼生期の評価指標としては, 現地観測による直接の 情報収集が困難であるので，数值シミュレーションに よる浮遊幼生の分散現象から間接的に評価する. その 際, 対象幼生の基本的な生物情報（放出のタイミング, 塩分選好性，運動特性）を室内実験等により把握して おくことが重要である. 本研究では FEM 平面 2 次元 浅水流計算で幼生分散および流れを検討した. 計算条 件等の詳細は文献 ${ }^{5)}$ を参照されたい。

\section{a) 1 潮汐間幼生移動距離}

$U c a$ 属の幼生は放出後, 親個体周辺の干潟に滞留 する傾向があることから，1 潮汐間の幼生の移動距離 は, 周辺水域の滞留機能や海水交換性のパラメータ となる.ここでは大潮の満潮時に各河川の Uca 属生 息地の中心から幼生の放出があったと仮定して, 餒 化直後の幼生の分散過程を Lagrange 的に追跡した. 吉野川河口における 1 潮汐間の幼生平均移動距離は $250 \mathrm{~m}$ 程度である.

\section{b) 生残率}

$U c a$ 属の幼生は大潮の高潮時に放出されることが 知られているが，特に放出直後は減耗率が大きく, 生残率は種の存続上重要な影響を及ぼす。ここでは 幼生の移動が河道内を離れて陸域に到達した場合に, 打ち上げられて死亡したものとみなすことで 1 潮汐 間に干潟に打ち上げられる割合を算出した。吉野川 河口での大潮満潮時に放出された幼生の生残率は約 $60 \%$ と算定された。

\section{c) 冠水時最大摩擦速度}

ここでは，冠水時最大摩擦速度を「干潟が冠水して いる時の局所水深 $h$ とエネルギー勾配 $I_{e}$ より計算さ
れる $u_{*}=\sqrt{g h\left|I_{e}\right|}$ の最大值」と定義する. エネルギ一勾 配 $I_{e}$ は Manning 式に Manning 粗度係数, 平面二次 元浅水流計算で得られる局所平均流速, 局所水位を 与えて算出した。 この指標は, 微細粒子の輸送に関 連が樑いと考えられる. 吉野川河口では, 平均 2〜 $3 \mathrm{~cm} / \mathrm{s}$ 程度の值が得られた.

\section{（3）地形に関する評価指標}

前節でも述べたように $U c a$ 属の保全を考えるにあ たっては，底質などの物理条件を考慮するだけでなく， 水域も含めた生息地周辺の地形そのものの保全が重要 である. 生息地および周辺の地理的条件を評価するた めに以下の指標を取り扱った.

\section{a) 植生度}

植生の存在は, 微細粒子のトラップや底質の変動 緩衝の効果があり, 個体群の安定には久かせない因 子となっている. 本研究では, 次式に示す植生度 $V E G_{i}$ を用いて, 干潟 $i$ の植生度の豊かさをあらわし た.

$$
V E G_{i}=\frac{n_{i}}{N_{i}}
$$

ここに, $n_{i}$ : 干潟 $i$ で植生の確認されたコドラート数, $N_{i}$ : 干潟 $i$ でのコドラートの総数. 吉野川河口の植 生度は 0.6 程度である.

\section{b) 高度}

高度は，底質指標と同様に人為的にも創造・管理可 能なパラメータとして重要である.この指標は干潟干 出時刻や活動可能時間と関係があり，摂飭効率と密接 な関係がある. シオマネキは潮間帯下部，ハクセンシ オマネキはシオマネキよりも数 $10 \mathrm{~cm}$ 高いところに生 息している. 吉野川河口では，シオマネキ生息地の平 均高度は T.P. $+10 \mathrm{~cm}$ 程度, ハクセンシオマネキは T.P. $+50 \mathrm{~cm}$ 程度である.

\section{c) 河口閉塞度}

河口閉塞度は, 波浪の程度, 幼生分散, 汽水域の塩 分環境等, $U c a$ 属の生息に大きな影響を及ぼす，本研 究では, 河口閉塞度を次式で定義した。

$$
C_{i}=1-\frac{b_{i}}{B_{i}}
$$

ここに, $C_{i}$ : 河川 $i$ の河口閉塞度, $b_{i}$ 砂州部を除く水 路幅， $B_{i}$ : 河道幅である. 図-2 に示される吉野川河 口部の閉塞度は約 0.45 である. 


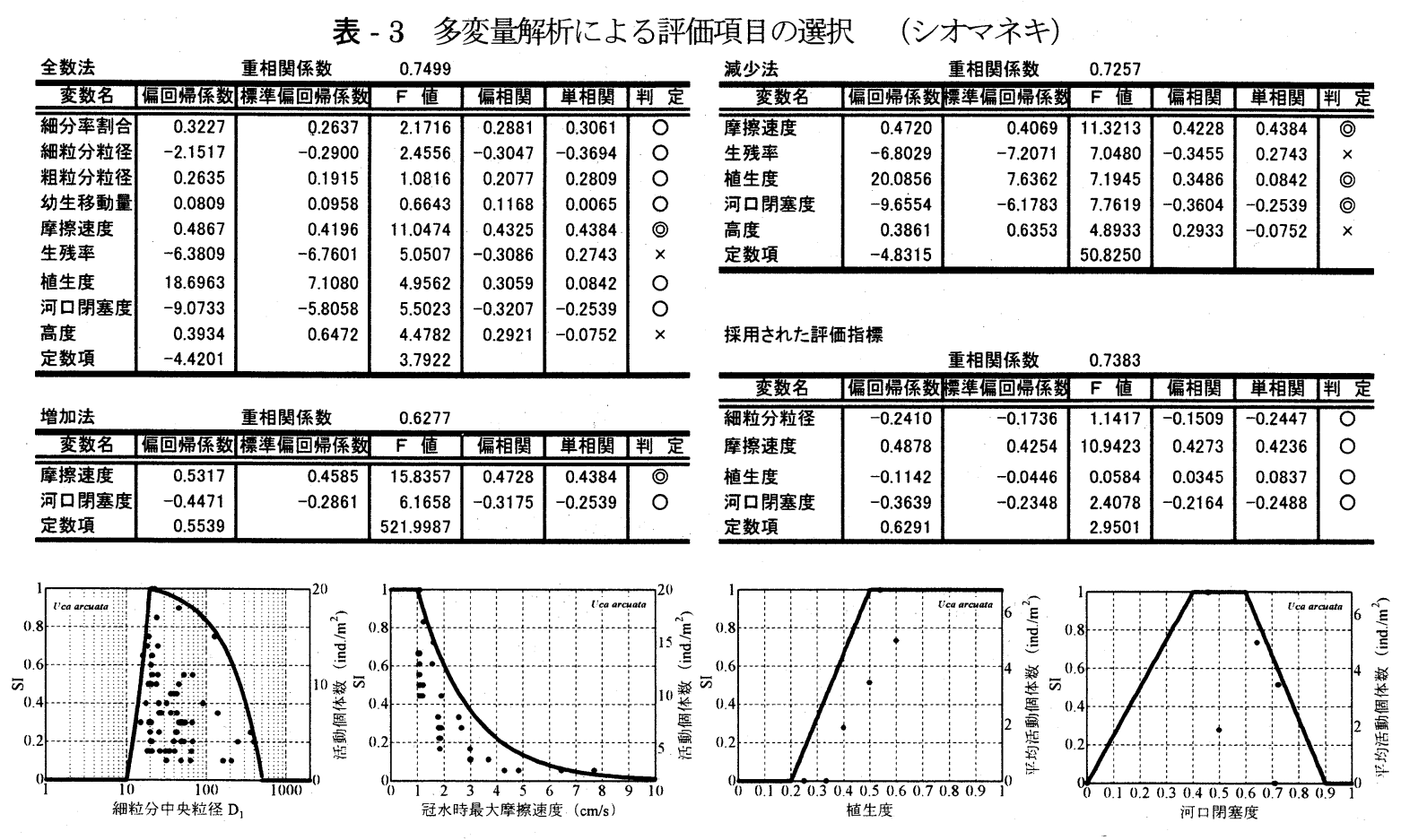

図ー4 シオマネキのSI モデル

以上が本研究で取り扱う評価指標である. Uca 属の 生態を取り扱う以上，塩分や栄養塩に関する指標につ いても検討する必要があるかもしれないが，ここでは

「干潟の修復・創造技術の確立」ということに重きを おいて, 人為的に創造・管理可能なもののみを評価指 標として取り扱うことにする.

\section{4. 重み付き評価指標を用いた HSI モデルの構築}

$U c a$ 属の生息地とその機能を評価するために HEP (Habitat Evaluation Procedure : 生物生息環境評価手順)の なかの HSI（Habitat Suitability Index : 生物生息環境適合 度指数）による生息地適性評価を実施した. HSI を評価 する手順は，まず，前節でとりあげた評価指標のうち $U c a$ 属日最大活動個体数之相関の強いものを多変量解 析により選択する. 次に，選択された因子について生息 環境の点数化をおこなう. 点数化にあたっては, 各因子 ごとに最大活動個体数を与える SI（Suitability Index : 適 性指数）モデルを作成する. これらを総合化して一つの 数值 HSI を求める.

(1)多変量解析による評価項目の選択

前節でとりあげた評価指標のうち, Uca 属活動個体 数と相関の強い因子を抽出するために, 多変量解析をお こなった. 種別の年間最大活動個体数で除して求めた 無次元 $U c a$ 属活動個体数を目的变数に, 各評価項目の 測定データを説明変数として, 多変量解析をおこない各 評価指標の重要度と説明変数としての有意性の検討をお こなう。このときの使用データは, 活動の高い $6 \sim 8$ 月 の調査データで, 気象等の要因をできるだけ除くために,
各観測日ごとの最大活動個体数とその時の測定值を使用 した. また, 多変量解析は, 全数法, 増加法 ( F 值 2.0 以上の説明変数を選択), 減少法 ( $\mathrm{F}$ 值 2.0 以下の説明 変数を除去) でおこなった. 得られた結果をもとに SI モデルで使用する変数を以下の基準で選択した.

【基淮 1】単相関係数と偏相関係数の符号が異なる評価 指標は多重共線性が高いので除去する.

【基淮 2】増加法, 減少法の両方で相関が高い（F值が 8 以上）と判断される評価指標を優先的に採 用する。

【基準 3】底質，流れ，地形に関する評価指標をそれぞ れで少なくとも 1 つ以上採用する.

【基淮 4】重相関係数が 0.70 以上とする.

シオマネキの場合について, 評価指標の選択手順を具 体的に説明する. まず, 全数法, 増加法, 減少法のそれ ぞれで，各評価項目の偏回帰係数，標準回帰係数，目的 関数（活動個体数）に対寸る影響力の検定 ( $\mathrm{F}$ 值), 目 的関数と説明変数との単相関・偏相関を調べる. ここで 【基準 1】にあてはまる生残率, 高度を説明変数として 除去する. 次に, 増加法, 隇少法の結果加【基淮 2】 を満たす摩擦速度, 植生度, 河口閉塞度を説明変数とし て採用する. これだけでは, 流れに関する評価指標が入 っていないので, 【基準3】を満足するために, 底質の なかでもっとも F 值の大きい細粒分粒径を採用する. 細粒分粒径, 摩擦速度, 植生度, 河口閉塞度の 4 つの指 標での重相関係数が 0.7383 と【基準 4】をクリアしてい るため, シオマネキの説明変数としてこれら 4 つの評価 指標をとりあげる. 八クセンについても同様の手順で選 択した. 選択された評価指標について SI モデルを作成 

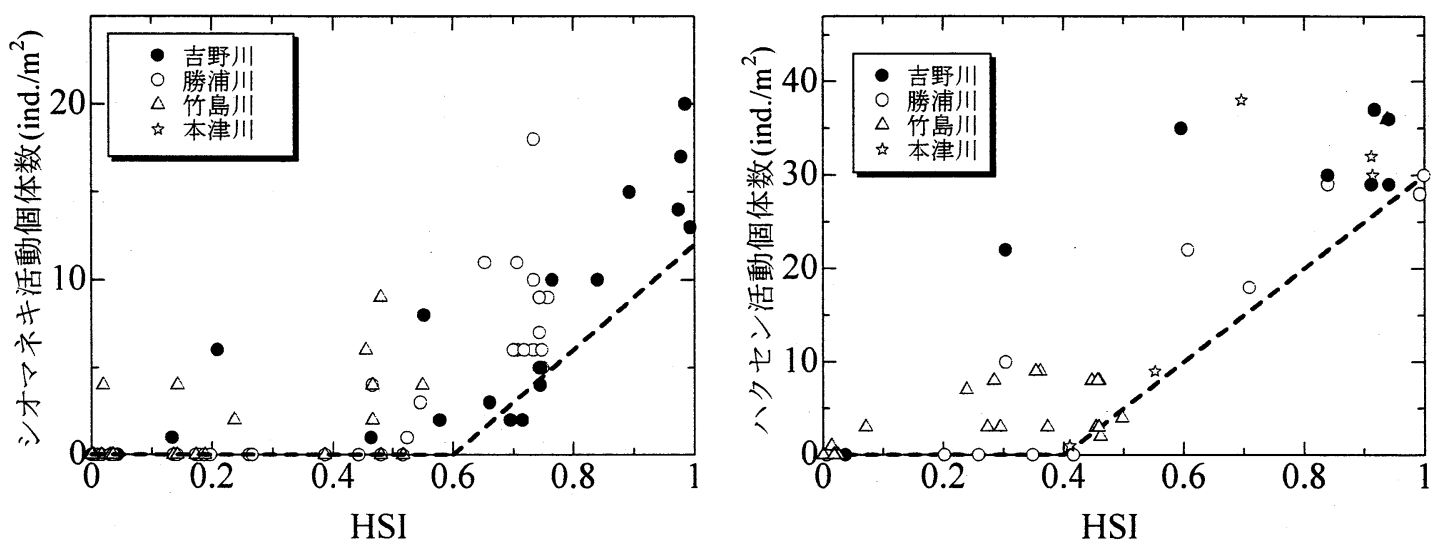

図-5 Uca 属活動個体数と HSI

する (図一4).SI モデルは最大活動個体数の包絡值を 結ぶように作成している。これはSI モデルにより表現 したいものは干潟での Uca 属生息数であり，これに年 間の最大活動個体数が相当すると考えたためである. SI モデルの作成方法の詳細は文献)を参照されたい．

SI モデルでは各指標が 0 と 1 の間をとるように基準 化されているが，従来のモデルでは指標間の重要度を考 慮できない.そこで, HSI を

$$
\mathrm{HSI}=\prod_{j=1}^{m}\left(\mathrm{SI}_{j}\right)^{W_{j}}
$$

のように重み係数w，を用いて表すことにした．式(3)の 左辺の説明変数に各 SI の対数值を用い，右辺の目的変 数に全干潟を対象にした年間最大活動個体数で基隻化さ れた日最大活動個体数の対数值を用いて, 線形回帰分析 を行い，各 SI の重みw，を計算した．重みを考慮した HSI の計算式は以下のようになる.

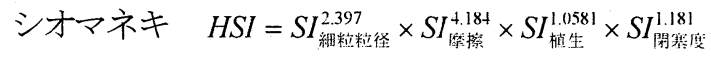

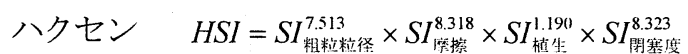

シオマネキ，八クセンシオマネキともに底面摩擦速度 SI の重みが大きく，この指標があらわす「微細粒子の 堆積」の程度がシオマネキ属の生息環境に大きく影響し ていることが予想される.

図一5にHSI とシオマネキの活動個体数との関係を 示す。この図より，生息限界 HSI はシオマネキで 0.6 , 八クセンシオマネキで 0.4 程度であることがわかる．本 来, 代償面積を決定するためにはHSI とシオマネキの 活動個体数は線形の関倸になる必要がある. しかし, 本 モデルでは限られた評価指標で HSI を算出しているた めに, HSI がある程度の点数の範冊にも関わらず，シ オマネキ属の活動個体数がゼロになることがある. 今後, モデルの精度向上にむけて，こうした地点についてより 詳細に環境因子の分析をおこなう必要があると思われる。

5. まとめ
本研究では, 干潟生物の生息地適性評価手法として, 重みつき評価指標を取り入れた HSI モデルについて論 じた. 評価指標の選択の際に統計的な取り扱い方をする ことで, 開発者の恣意によらないより客観的なモデル構 築の可能が示唆された. 今後は河床変動計算の結果等を 考慮し, 河床動態が稀少生物の生息地に与える影響を考 慮しうるモデルに発展させていきたいと考えている.

\section{参考文献}

1)新保裕美, 田中昌宏, 池谷毅, 林文慶: 干潟における生物生 息環境の定量的評価に関する研究 - 多毛類を対象として一, 海岸工学論文集, 第 48 巻, pp.1321-1325, 2001.

2)新保裕美, 田中昌宏, 池谷毅, 越川義功 : アサリを対象とし た生物生息地適性評価モデル, 海岸工学論文集, 第 47 巻, pp.1111-1115, 2000.

3)林文慶, 高山百合子, 田中昌宏, 上野成三, 新保裕美, 織田 幸伸, 池谷毅, 勝井秀博: 沿岸域における複数生物の生息地 評価 - 生態系連続性の配慮にむけて - , 水工学論文集, 第 46 巻, pp.1193-1198, 2002.

4)宇野宏司, 中野晋 : 四国地方における稀少種「シオマネキ」の 生息環境特性，地球環境シンポジウム講演論文集，vol.8， pp.99-104, 2000.

5)宇野宏司, 中野晋 : 四国周辺の干潟における稀少種「シオマ ネキ」生息地適性評価, 海洋開発論文集, vol.18, pp.185-190, 2002.

6)清野聡子, 塩崎正孝, 宇多高明, 後藤隆, 黒木利幸, 中村由 行 : 空中写真による干潟の微地形判読と現地調査を組み合 わせたカブトガニ生息地・産卵地調査法, 水工学論文集, 第 45 巻, pp.1021-1026, 2001.

7)大谷拓也 : シオマネキ幼生の飼育と観察, 水産増殖, Vol.37-4., pp.297-301, 1995.

8)小野勇一：干潟のカ二の自然誌，平凡社自然叢書 29, 271p., 1995.

9)山口隆男 : ハクセンシオマネキの生態 (I), CALNUS, NO.2, 1970.

(2002. 9. 30受付) 